\title{
Geno- and cytotoxicologic assessment of wastewater effluents with mussel micronucleus assay and with flow cytometric sperm toxicity assay: a comparison.
}

\author{
Balázs Kakasi, Eszter Horváth, Nóra Kováts, Bettina Eck-Varanka, Gábor Paulovits, Szabolcs Tamás Nagy
}

\begin{abstract}
Several pharmaceutical drugs have potential harmful effect on wildlife such as aquatic toxicity, genotoxicity, or endocrine disruption effect. Removal rates of pharmaceuticals from municipal sewage during waste water treatment is questionable, several studied drugs are insufficiently or not removed while passing through the sewage treatment plants (STP).The analytical monitoring of potentially harmful drugs and especially drug residues in influent and effluent of STP are rather costly and not always possible on a day to day basis. Toxicity bioassays, on the other hand, are relatively cost-effective short-term tests, estimating the aggregate genotoxicity of the samples on different taxonomic levels. In our study the cyto- and genotoxicity of the pre-treated potentially pharmaceutical containing influent and the effluent sample of a Hungarian STP were estimated with mussel (Unio pictorum) micronucleus (MN) assay and flow cytometric boar spermatozoa assay. The influent induced in the flow cytometric assay significant changes in mitochondrial transmembrane potential, oxidative DNA lesions and DNA fragmentation, but no significant genotoxic effect was detected by the MN assay. These results point to deficiencies of present wastewater treatment systems and remind us to choose carefully among available toxicity assays.
\end{abstract}

Keywords - genotoxicity, cytotoxicity, pharmaceutical sewage, micronucleus assay, flow cytometric spermatozoa assay

\section{Introduction}

It is one of the major challenges in the wastewater treatment industry to remove pharmaceuticals from effluents.

\section{Balázs Kakasi}

Research Institute of Chemical and Process Engineering, University of Pannonia

Hungary

Eszter Horváth (corresponding author), Nora Kováts, Bettina Eck-Varanka University of Pannonia, Institute of Environmental Sciences Hungary

Gábor Paulovits

MTA Centre for Ecological Research, Balaton Limnological Institute Hungary

\section{Szabolcs Tamás Nagy}

Georgikon Faculty, Department of Animal Sciences and Animal Husbandry, Georgikon Faculty, University of Pannonia Hungary
At present, removal rates of pharmaceuticals from municipal effluents during waste water treatment is questionable, several studied drugs are insufficiently or not removed while passing through the sewage treatment plants (STP). Drugs or their metabolites are already present in freshwater ecosystems [1], they have even been found to occur in the sediment at concentrations much higher than in the water column or wastewater treatment plants effluents [2].

Several pharmaceutical drugs have potential harmful effect on wildlife such as aquatic toxicity, genotoxicity, or endocrine disruption effect $[3,4,5]$ The environmental importance of mixtures of pharmaceutical residues are reviewed by Vasquez et al. [6].

The analytical monitoring of potentially harmful drugs and especially drug residues in influent and effluent of STP are rather costly and not always possible on a day to day basis. Toxicity bioassays, on the other hand, are relatively costeffective short-term tests, estimating the aggregate genotoxicity of the samples on different taxonomic levels.

In our study the performance of a Hungarian STP was estimated with mussel (Unio pictorum) micronucleus (MN) assay and flow cytometric boar spermatozoa assay. The STP collects and treats municipal effluent (from a medium-sized town) and also receives the pre-treated effluent of a pharmaceutical firm.

The mussel micronucleus assay is based on the ratio of micronuclei formation which indicates mitotic chromosome breakage or chromosome mis-segregation [7] It has been successfully applied for assessing the genotoxic potential of selected drugs, of treated effluents [8, 9] or in case of freshwater environments receiving urban effluents [10]. On the contrary, the boar spermatozoa biosensor, which was first used for toxin detection in dust samples [11], has never been applied for wastewater genotoxicity assessment.

\section{Materials and methods}

Sewage samples were collected in a Hungarian municipal treatment plant. Sample 1 was taken from the pretreated pharmaceutical wastewater which goes to the treatment plant, together with the municipal raw wastewater. Sample 2 was taken from the effluent. The micronucleus test was initiated directly after sampling. The sample was kept at $-18^{\circ} \mathrm{C}$ until cytometric boar spermatozoa assay was performed. 


\section{A. MN test}

MN test was performed on Unio pictorum specimens with length of $5-8 \mathrm{~cm}$ collected from Lake Balaton. Prior to the testing, animals were acclimatized for 4 weeks $(\mathrm{t}=18$ $24^{\circ} \mathrm{C}, \mathrm{DO}=85-93 \%$ ). The assay was performed based on the protocol described by Wozniczki et al. [12], with some modifications. Treatments were performed in 3 replicates, on five animals, in 31 water volume each. Aquaria were aerated during the experiment, temperature was set at $22{ }^{\circ} \mathrm{C}$. Exposure time was 4 days. 10x, 20x, 30x and 40x dilutions were set. For dilution and for control water from Lake Balaton was used. A semi-static test arrangement was chosen, to avoid organic compound degradation induced toxicity, so the test solution was changed after 2 days of exposition.

After 4 days, haemolymph was taken from the posterior adductor muscle using the non-lethal technique described by Gustafson et al. [13]. Sample fixation and Giemsa staining method is described by Eck-Varanka et al [14].

Photos were taken by a Zeiss AxioScope A1 microscope with an AxioCam ICC1 camera and Zen 2011 program at 400x magnification. Micronuclei were identified according to Fenech [15].

\section{B. Semen samples}

Boar sperm samples extended with commercial extender (Androstar Plus - Minitube) to approximately 30 million spermatozoa per $\mathrm{ml}$ were acquired from a local pig breeding farm. Actual cell concentrations were montiored with a Minitube SDM-1 photometer, calibrated for porcine sperm. Cells were used within 2-3 days after collection.

\section{Flow cytometric boar sperm assay}

Flow cytometric assay was performed according to Anderson et al. [16]. Briefly: 200-200 $\mu$ l extended boar semen was exposed to 20-20 $\mu$ PBS supplemented (one PBS tablet (Sigma) dissolved in $200 \mathrm{ml}$ sample) sewage samples, and incubated at room temperature for 30 minutes in dark. Cells were evaluated by a Beckman Coulter FC500 flow cytometer (Beckman Coulter, Inc., Brea, CA, USA) equipped with a $488 \mathrm{~nm} 20 \mathrm{~mW}$ Ar ion laser and a $635 \mathrm{~nm}$ $25 \mathrm{~mW} \mathrm{HeNe}$ laser. The acquisition record settings were $300 \mathrm{sec}$ or 20.000 events. Cells were identified by light scatter (FSC-SSC) properties and non-sperm related events were gated out. Files were stored as list mode (LMD) files. List mode files were analysed with Flowing Software (Version 2.5.1, http://www.flowingsoftware.com).

\section{Mitochondrial transmembrane potential measurement}

Mitochondrial transmembrane potential was evaluated by Mitotracker Green FM (MitoTracker® Green FM Molecular Probes) and Mitotracker Deep Red dye (MitoTracker® Deep Red FM - Molecular Probes) stains: 5$5 \mu \mathrm{l}(0.1 \mathrm{mM}$ in DMSO) of the probes were added to the test tubes, incubated in dark at room temperature for 10 minutes, and measured, according to Ajao [17]. The median fluorescence intensities of the of FL4Log/FL1Log ratio was presented on a histogram, showing the events of sperm population, indicating the active mitochondria/all mitochondria proportion, which is a relative measure of the mitochondrial membrane potential changes

\section{E. Oxidative DNA lesions}

Oxidative DNA lesions were detected with the OxyDNA test (Argutus Medical BIO81DNA) based on a FITCconjugated 8-oxoguanine specific antibody. Test was carried out according to the test manual [18].

\section{F. Nicoletti DNA fragmentation assay}

DNA fragmentation assay was carried out according to Riccardi and Nicoletti [19]. Cells were washed in PBS, and resuspended in equal volume of Fluorochrome solution $\left(0.1 \%\right.$ sodium citrate, $0.1 \%$ Triton $\mathrm{X}-100$ and $50 \mathrm{mg} \mathrm{l^{-1 }}$ Propidium Iodide in distilled water). Cells were incubated at $\left(4{ }^{\circ} \mathrm{C}\right)$ for $1 \mathrm{~h}$, than measured with the previously described cytometer, according to Kakasi et al.[20].

\section{G. Statistical analysis}

For MN test 1000 cells were counted from each animal. One-way ANOVA with Tukey post hoc test was used to compare the mean $\mathrm{MN}$ numbers between the treatments.

For flow cytometric analysis results were compared to control using Yates corrected Chi-square to determine the relations of the data. The statistical analysis was performed using GraphPad QuickCalcs software (http://graphpad.com/quickcalcs).

\section{Results}

Genotoxic response in mussel micronucleus test was expressed as number of micronuclei/1000 cells. No significant differences between the number of micronuclei in samples compared to control was detected, (ANOVA: $\mathrm{df}=2$ $\mathrm{F}=0.5402 \mathrm{p}=0.5918$; influent-control Tukey post hoc: $\mathrm{p}=0.8477$, effluent-control Tukey post hoc: $\mathrm{p}=0.8774)($ Fig $1)$.

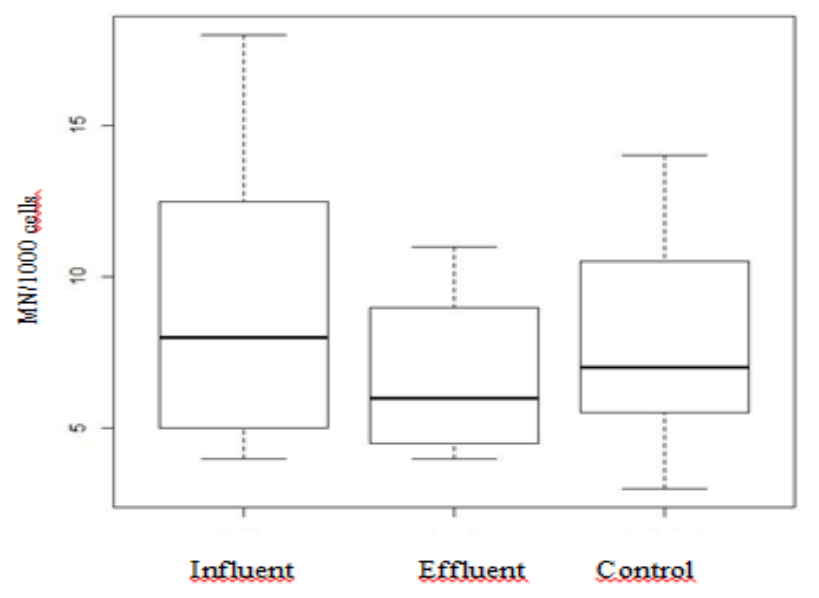

Figure 1. Results of MN test with the influent and effluent sewage samples.

In Nicoletti assay a slight fragmentation of control sperm DNA was detected $(0.02 \pm 0.02 \%)$. Fragmentation increased slightly in response to the incubation with influent sewage samples, but fragmented DNA percentage was rather low (Table 1). Fig 2 shows the ratio of fragmented DNA in control (A) and in influent (B) sewage sample. Effluent had 
Proc. of the Third Intl. Conf. on Advances in Bio-Informatics and Environmental Engineering - ICABEE 2015

Copyright (C) Institute of Research Engineers and Doctors, USA .All rights reserved.

ISBN: 978-1-63248-078-1 doi: 10.15224/ 978-1-63248-078-1-70

no significant DNA fragmentation effect in spermatozoa. (Table 1)

TABLE I. RESUL TS OF FLOW CYTOMETRIC SPERMCATOZOA ASSAY

\begin{tabular}{|l|c|c|c|}
\hline Sample & Active mitochondria (\%) & Oxidized DNA (\%) & Fragmented DNA (\%) \\
\hline Control & $87.18 \pm 0.91$ & $3.19 \pm 1.61$ & $0.02 \pm 0.02$ \\
\hline Sample 1 & $83.62 \pm 0.84$ & $2.97 \pm 0.61$ & $0.10 \pm 0.04$ \\
\hline Sample 2 & $34.59 \pm 5.59$ & $14.57 \pm 2.46$ & $0.60 \pm 0.15$ \\
\hline
\end{tabular}
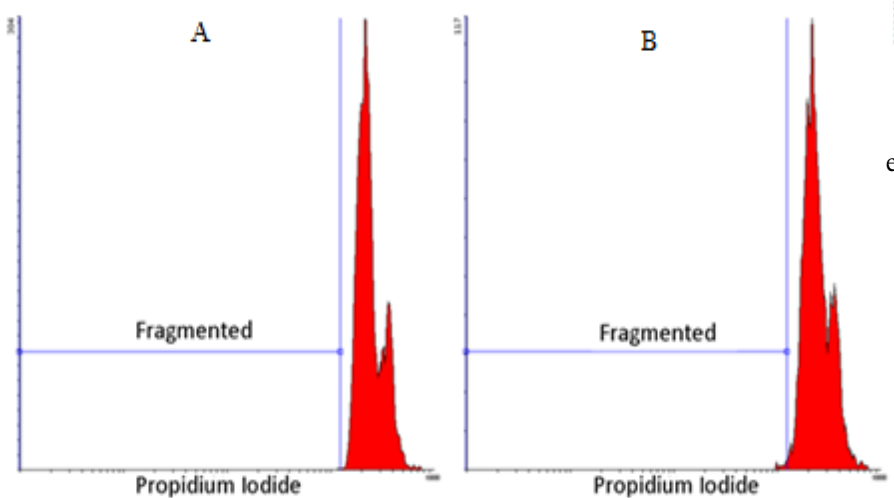

Figure 2. Flow cytometric histogram of sperm cells analysed for propidium iodide fluorescence (DNA content) in the control (A) and in the influent sewage sample (B)

Influent samples had more severe impact on mitochondrial activity and oxidized DNA percentage in sperm cells - after 30 minutes exposure the ration of oxidized DNA increased from $3.19 \pm 1.61$ to $14.57 \pm 2.46$ in case of influent sample, and mitochondrial activity decreased from $87.18 \pm 0.91$ to $34.59 \pm 5.59$ respectively (Table 1 , Fig, 3 Fig 4)

Exposure to effluent sewage sample caused no increment in oxidized DNA percentage, and alteration in mitochondrial activity was not detectable in spermatozoa (Table 1).
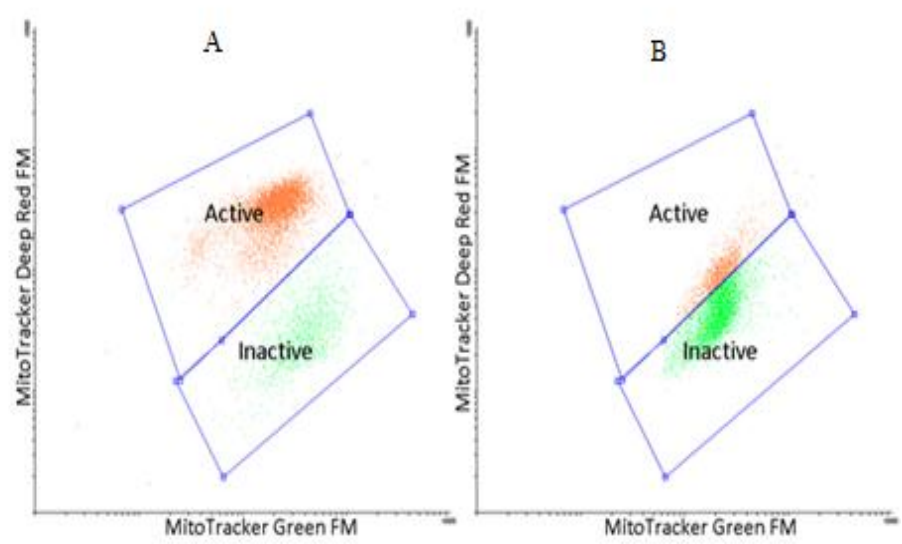

Figure 3. The ratio of active and inactive mitochondria indicating mitochondrial membrane potential alteration in case of the control (A) and influent sewage sample (B)
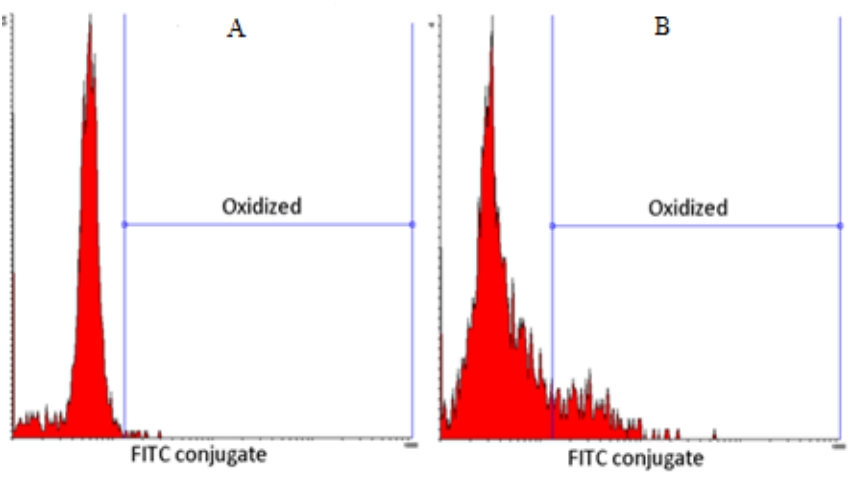

Figure 4. Oxidative DNA lesions in spermatozoa after 30 minutes exposure in the control (A) and in the influent sewage sample (B)

\section{Discussion}

The release of pharmaceuticals from sewage effluents to the environment is a growing concern. The presence of pharmaceuticals in municipal sewage during waste water treatment can lead to reduced overall performance due to the toxicity of drugs to the microbial community of the STP [21]. Due to insufficient removal potentially harmful active components can be often detected in various concentrations in STP effluents, greatly endangering the organisms in the recipient waters [21, 22]. Chemical evaluation of complex waste water samples did not always correspond to ecotoxicity, so it is essential to complement chemical evaluation of municipal waste waters with ecotoxicological testing on different trophic levels [23].

In our study the pre-treated pharmaceutical wastewater influent and the effluent of a Hungarian STP were evaluated with the micronucleus (MN) test - a well known method in environmental toxicity testing - and with a new boar spermatozoa flow cytometric assay, analysing DNA fragmentation, oxidative DNA lesions and mitochondrial activity.

Although flow cytometric boar spermatozoa assay indicated significant oxidative DNA lesion induction and drastic mitochondrial activity decrease in the influent sample, there was no significant $\mathrm{MN}$ ratio increase to either of the sewage samples examined in our study. The mussel MT test is a widely used genotoxicity biomarker in aquatic environment, and its sensitivity to genotoxic pharmaceuticals and genotoxic effluents is proved with the endpoint of DNA breakage and chromosome loss during mitosis $[24,8,9]$. In corresponds to this result, the Nicoletti assay resulted only in low DNA fragmentation increment in boar spermatozoa. Thus negative genotoxic response of $\mathrm{MN}$ test indicates that for this type of wastewaters, the endpoint is inadequate.

According to these result we describe a new, not commonly applied and very sensitive test to evaluate ecotoxicity of treated waste water samples on eukaryote models, unfortunately the high costs of flow cytometric measurements prevents the application of this technology in day to day wastewater ecotoxicity testing. 
Proc. of the Third Intl. Conf. on Advances in Bio-Informatics and Environmental Engineering - ICABEE 2015

Copyright (C) Institute of Research Engineers and Doctors, USA .All rights reserved.

ISBN: 978-1-63248-078-1 doi: 10.15224/ 978-1-63248-078-1-70

\section{Acknowledgments}

We acknowledge the financial support of the Hungarian State and European Union under the

TÁMOP-4.2.2.B-15/1/KONV-2015-0004 project.

\section{References}

[1] A. Nikolaou, S. Meric, and Fatta D. "Occurrence patterns of pharmaceuticals in water and wastewater environments." Anal Bioanal Chem, vol. 387, pp. 1225-1234, 2007.

[2] L.A. Maranho, R.M.Baena-Nogueras, P.A. Lara-Martín, T.A. Del Valls, M.L. Martín-Díaz. "Bioavailability, oxidative stress, neurotoxicity and genotoxicity of pharmaceuticals bound to marine sediments. The use of the polychaete Hediste diversicolor as bioindicator species.” Environmental Research vol. 134, pp. 353-365, 2014.

[3] B. Quinn, F. Gagné, C. Blaise, "An investigation into the acute and chronic toxicity of eleven pharmaceuticals (and their solvents) found in wastewater effluent on the cnidarians, Hydra attenuate." Sci.Total Environ. ol. 389(2-3), pp. 306-314, 2008.

[4] L. Martín-Díaz, S. Franzellitti, S. Buratti, P. Valbonesi, A. Capuzzo, E. Fabbri, "Effects of environmental concentrations of the antiepilectic drug carbamazepine on biomarkers and cAMP-mediated cell signaling in the mussel Mytilus galloprovincialis." Aquat.Toxicol. vol. 94(3),pp. 177-185, 2009.

[5] G.V. Aguirre-Martínez, T.A. DelValls, M.L. Martín-Díaz, "Early responses measured in the brachyuran crab Carcinus maenas exposed to carbamazepine and novobiocin: application of a 2-tier approach." Ecotoxicol.Environ.Saf. vol. 97, pp. 47-58, 2013.

[6] M.I. Vasqueza, A. Lambrianides,2, M. Schneider, K. Kümmerer, D. Fatta-Kassinosa, "Environmental side effects of pharmaceutical cocktails: What we know and what we should know." J. Hazard Mater vol. 279, pp. 169-189, 2014.

[7] M.I. Kirsch-Volders, M. Fenech, "Inclusion of micronuclei in nondivided mononuclear lymphocytes and necrosis/apoptosis may provide a more comprehensive cytokinesis block micronucleus assay for biomonitoring purposes.” Mutagenesis. vol. 16(1), pp.51-58, 2001.

[8] M. Parolini, A. Binelli, D. Cogni, A. Provini, "Multi-biomarker approach for the evaluation of the cyto-genotoxicity of paracetamol on the zebra mussel (Dreissena polymorpha)." Chemosphere vol. 79 pp. 489-498, 2010.

[9] A. de los Ríos, L. Pérez, M. Ortiz-Zarragoitia, T. Serrano, M.C. Barbero, B. Echavarri-Erasun, J.A. Juanes, A. Orbea, M.P. Cajaraville, "Assessing the effects of treated and untreated urban discharges to estuarine and coastal waters applying selected biomarkers on caged mussels." Marine Pollution Bulletin, vol. 77 pp. 251-265, 2013

[10] S. Kolarević, J. Knežević-Vukčević, M. Paunović, J. Tomović, Z. Gačic, B. Vuković-Gačić, "The anthropogenic impact on water quality of the River Danube in Serbia: microbiological analysis and genotoxicity monitoring." Archives of Biological Science. Belgrade vol 63(4), pp. 1209-1217, 2009.

[11] M.A. Andersson et al. "Boar spermatozoa as a biosensor for detecting toxic substances in indoordust and aerosols." Toxicol.in Vitro vol. 24, pp. 2041-2052, (2010)

[12] P. Woźnicki, R. Lewandowska, P. Brzuzan, E. Ziomek and R. Bardega,"The level of DNA damage and the frequency of micronuclei in haemolymph of freshwater mussels Anodonta woodiana exposed to benzo[a]pyrene," Acta Toxicol. vol. 12(1), pp. 41-45, 2004.

[13] L. L.Gustafson, M. K. Stoskopf, A. E. Bogan,W. Showers, T. J. Kwak, S. Hanlon and J. F. Levine, "Evaluation of a nonlethal technique for hemolymph collection in Elliptio complanata, a freshwater bivalve (Mollusca: Unionidae)," Dis. Aquat. Organ. vol. 65, pp. 159-165, 2005.

[14] B. Eck-Varanka, E. Horáth, Á. Ferincz, G. Paulovits, N. Kováts, "Comparative Assessment of the Mussel Micronucleus Test Versus Bacterial Bioassays for Genotoxicity Testing of Benzo[a]pyrene" ol 42, No 1 (2014): Hungarian Journal of Industry and Chemistry

[15] M. Fenech and S. Neville, "Conversion of excision-repairable DNA lesions to micronuclei within one cell cycle in human lympho-cytes," Environ. Mol. Mutagen. vol. 19(1), pp. 27-36, 1992.
[16] M.A.Andersson, E.L. Jaaskelainen, R. Shaheen, T. Pirhonen, L.M. Wijnands, M.S. Salkinoja-Salonen, "Sperm bioassay for rapid detection of cereulide-producing Bacillus cereus in food and related environments." International journal of food microbiology, vol. 94, pp. 175-183, 2004.

[17] C. Ajao, M.A. Andersson, V. V. Teplova, S. Nagy, C.G. Gahmberg, L. C. Andersson, L. C., M.Hautaniemi, B. Kakasi, M.Roivainen, Salkinoja-Salonen, M., "Mitochondrial toxicity of triclosan on mammalian cells.” Toxicology Reports, vol. 2, pp. 624-637, 2015

[18] P.F. Silva, B.M. Gadella, B. Colenbrander, B. A.Roelen, “ Exposure of bovine sperm to pro-oxidants impairs the developmental competence of the embryo after the first cleavage." Theriogenology, vol. 67(3),pp. 609-619, 2007.

[19] C. Riccardi, I. Nicoletti, "Analysis of apoptosis by propidium iodide staining and flow cytometry." Nature protocols, vol. 1, pp 1458-1461., 2006.

[20] B. Kakasi, S. Nagy, L. Pál, G. Czimber, F. Husvéth, “ A comparison of alternative assays to measure DNA damage in stallion spermatozoa: TUNEL test versus 'Nicoletti assay'،, Acta Veterinaria Hungarica, vol. 63(1), pp. 118-124, 2015.

[21] D.G.Larsson, C. de Pedro, N. Paxeus, "Effluent from drug manufactures contains extremely high levels of pharmaceuticals.", J Hazard Mater. vol. 148(3), pp. 751-5, 2007.

[22] R. Gurke, M. Rößler, C. Marx, S. Diamond, S. Schubert, R. Oertel, J. Fauler, "Occurrence and removal of frequently prescribed pharmaceuticals and corresponding metabolites in wastewater of a sewage treatment plant." Science of The Total Environment, vol. 532, pp. 762-770, 2015.

[23] E. Mendonça, A. Picado, S.M. Paixão, L. Silva, M.A. Cunha, S. Leitão, I. Moura, C. Cortez, F. Brito, "Ecotoxicity tests in the environmental analysis of wastewater treatment plants: Case study in Portugal." Journal of hazardous materials vol. 163.2, pp.665-670, 2009.

[24] C. Bolognesi, M. Fenech, "Mussel micronucleus cytome assay", Nature protocols, vol.7(6), pp. 1125-1137, 2012. 